\title{
Stéphane Michaud, Les tremblements de la beauté
}

\section{Brenda Piselli}

\section{(2) OpenEdition}

\section{Journals}

\section{Edizione digitale}

URL: https://journals.openedition.org/studifrancesi/26657

DOI: 10.4000/studifrancesi.26657

ISSN: 2421-5856

\section{Editore}

Rosenberg \& Sellier

\section{Edizione cartacea}

Data di pubblicazione: 1 avril 2007

Paginazione: 204-205

ISSN: 0039-2944

\section{Notizia bibliografica digitale}

Brenda Piselli, «Stéphane Michaud, Les tremblements de la beauté», Studi Francesi [Online], 151 (LI | I) | 2007, online dal 30 novembre 2015, consultato il 23 novembre 2021. URL: http://

journals.openedition.org/studifrancesi/26657 ; DOI: https://doi.org/10.4000/studifrancesi.26657

Questo documento è stato generato automaticamente il 23 novembre 2021.

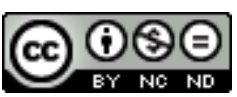

Studi Francesi è distribuita con Licenza Creative Commons Attribuzione - Non commerciale - Non opere derivate 4.0 Internazionale. 


\title{
Stéphane Michaud, Les tremblements de la beauté
}

\author{
Brenda Piselli
}

NOTIZIA

STÉPHANE MICHAUD, Les tremblements de la beauté, Revue d'Histoire Littéraire de la France», $105^{\mathrm{e}}$ année, n. 4, octobre 2005, pp. 951-964.

1 L'A. studia il concetto di «beauté tremblante [...]» (p. 952) attraverso l'opera di Jean Paul Richter, Goethe, Hoffmann, Heine e Hölderlin, autori la cui poetica influenzò dapprima Baudelaire e, in epoca più recente, Pierre Jean Jouve, Yves Bonnefoy e Michel Deguy. Michaud mette quindi in luce il rapporto Baudelaire/Nietzsche da un lato e Baudelaire/Jouve-Bonnefoy dall'altro, per concludere che, secondo Claude Pichois, editore di Baudelaire per la Biblioteca della Pléiade, questa particolare idea di Bello rappresenta uno dei molteplici volti della modernità. 